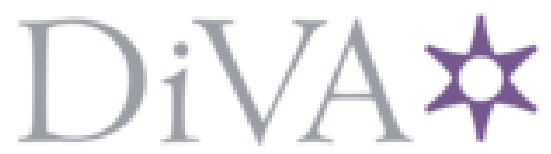

http://www.diva-portal.org

This is the published version of a chapter published in Disputed Memories: Emotions and Memory Politics in Central, Eastern and South-Eastern Europe.

Citation for the original published chapter:

Kotljarchuk, A. (2016)

The Memory of Roma Holocaust in Ukraine. Mass Graves, Memory Work and the Politics of Commemoration.

In: Tea Sindbæk Andersen \& Barbara Tornqvist-Plewa (ed.), Disputed Memories: Emotions and Memory Politics in Central, Eastern and South-Eastern Europe (pp. 149-176). Berlin-Boston:

Walter de Gruyter

Media and Cultural Memory

https://doi.org/10.1515/9783110453539-007

N.B. When citing this work, cite the original published chapter.

AK har fått ok av förlaget/170228 GL

Permanent link to this version:

http://urn.kb.se/resolve?urn=urn:nbn:se:sh:diva-31342 


\title{
The Memory of the Roma Holocaust in Ukraine: Mass Graves, Memory Work and the Politics of Commemoration
}

\author{
Blood and screaming at Babi Yar! \\ There are thousands of graves over disadvantaged and persecuted victims \\ No granite stones on the graves of murdered Roma.
}

Mikha Kozimirenko, Romani-Ukrainian poet (1938-2003)

Thousands of Soviet Roma were killed in 1941-1944 by Nazi Einsatzgruppen and local collaborators. They were almost never deported to extermination camps, but instead their bodies were left at the scenes where these crimes were committed. In the protocols of the Soviet Extraordinary Commission for Investigation of War Crimes, the Roma were often counted as murdered civil citizens, without specifying their ethnicity. Despite the existence of a small number of accounts identifying the victims of these murders as Romani, the Roma part of the Holocaust history is still little known in post-Soviet space. ${ }^{1}$

In 1976 an official memorial at Babi Yar was erected in Kyiv on the location of the largest massacre during WWII of Eastern European Jews and Roma. However, the Soviet leadership discouraged placing any emphasis on ethnic aspects of this tragedy. The Nazi policy of extermination of Roma was neglected; the war was depicted as a tragedy for all Soviet peoples. ${ }^{2}$

The discussion of the Romani identity cannot be isolated from the memory of the genocide during WWII, which makes the struggle over the past a reflexive landmark that organizes the politics of commemoration. ${ }^{3}$ There are 47,000 Roma

1 This study was supported by the Foundation for Baltic and East European Studies (Sweden) and Södertörn University as a part of the research project "The Roma Genocide in Ukraine 1941 - 1944: History, memories and representations". The author wishes to thank Piotr Wawrzeniuk, David Gaunt, Anders Blomqvist (Södertörn University), Matthew Kott (Uppsala University), Mikhail Tyaglyy (Ukrainian Centre for Holocaust Stuidies), Barbara Törnquist-Plewa (Lund University) and anonymous reviewers for their comments and suggestions on prior drafts. 2 Alaina Lemon. Between two fires Gypsy performance and Romany memory. From Pushkin to Postsocialism. Durham: Duke University Press, 2000, 148.

3 Adam Bartosz. Tabor Pamieci Romow. Tarnow: Regional Museum of Tarnow Press, 2003; Elena Marushiakova and Vesselin Popov. "Holocaust and the Gypsies. The Reconstruction of the Historical Memory and Creation of New National Mythology." Beyond Camps and Forced Labour. Current International Research on Survivors of Nazi Persecution. Eds. Johannes-Dieter Steinert and Inge Weber-Newth. Osnabrück: Secolo, 2006, 805-826; Slawomir Kapralski. "Symbols 
in contemporary Ukraine. ${ }^{4}$ The Roma minority is often associated with poverty and crime, which has in turn converted it into a marginalized social group. ${ }^{5}$ In 1991 the government of independent Ukraine allowed the establishment of new memorials at Babi Yar that specifically identified the ethnicity of victims. A Jewish memorial was built in the same year. ${ }^{6}$ A Roma memorial is still under construction. In addition, about 20 monuments to victims of the Roma genocide have been erected in Ukraine during the last ten years. However, dozens of Roma mass graves remained unmarked and in need of elementary preservation and commemoration. The controversial battles over commemoration of WWII and the Holocaust in Ukraine make this process much more complicated; ${ }^{7}$ and scholars still do not have a clear picture of what is going on with post-Soviet politics of commemoration of the Roma genocide.

\section{Sources}

The author has used a wide range of sources. Among them are media publications, protocols of the Extraordinary Commission for Investigation of War Crimes (ChGK), articles of local historians, and photos. Most of the material for this article was collected during field research in 2010 and 2012. In September 2010 the author, together with colleagues from the French centre Yahad-In Unum and Södertörn University, participated in field research in Volhynia. In July-August 2012 an independent expedition to Kyiv, Poltava, Vinnitsa, Sumy and Chernihiv regions was carried out. Field work included interviews with witnesses of geno-

and Rituals in the Mobilisation of the Romani National Ideal." Studies in Ethnicity and Nationalism 12.1 (2012): 64 -81; Andrej Kotljarchuk. "World War II Memory Politics: Jewish, Polish and Roma Minorities of Belarus.” The Journal of Belarusian Studies 1.7 (2013): 7 - 40.

4 All-Ukrainian census 2001.

5 Oleksandr Belikov. "Derzhavna politika stosovno tsygan Ukrainy: istoria i suchasnist." Naukovi zapiski. Zbirnik prats molodikh vchenikh ta aspirantiv. Kyiv: National Academy of Sciences, 2008, 24-56.

6 Tatiana Evstafieva. "K istorii ustanovleniya pamiatnika v Bab’em Yaru.” Evreiskii obozrevatel. 11 (30 June 2002).

7 Jeff Mankoff. "Babi Yar and the struggle for memory, 1944-2004." Ab Imperio 2 (2004): 393 - 415; Rebecca Golbert. "Holocaust Sites in Ukraine: Pechora and the Politics of Memorialization.” Holocaust and Genocide Studies 18.2 (2004): 205-233; Wilfried Jilg. "The Politics of History and the Second World War in Post-Communist Ukraine.” Jahrbücher für Geschichte Osteuropas 54.1 (2006): 50-81; Omer Bartov. Erased: vanishing traces of Jewish Galicia in present-day Ukraine. Princeton: Princeton University Press, 2007; Aleksandr Burakovsky. "Holocaust remembrance in Ukraine: memorialization of the Jewish tragedy at Babi Yar." Nationalities Papers 39.3 (2011): $371-389$. 
cide, local experts and agents of memory. The field research also included geographic and photographic investigation of memory objects. Simultaneously expositions in local museums were investigated.

\section{Aims and theoretical framework}

The purpose of the present study is to analyze the Soviet and contemporary politics of memory regarding the Roma Holocaust in Ukraine with the focus on memorials and mass graves. The principal questions are:

- What role does Ukraine's past dependence on the Soviet period play in the contemporary politics of the memory of the Roma genocide in Ukraine?

- What are the causes of the active memorial work in contemporary Ukraine regarding the Roma Holocaust mass graves?

- Who are the agents of memory?

- What external and internal factors play a role in this segment of the memory policy?

These questions acquire a special interest in a comparative perspective. In Russia, there are no monuments in the places of the mass executions of Roma that indicate the ethnicity of the victims. Belarus has only three such sites. ${ }^{8}$ At the same time more than twenty monuments have been raised over the past ten years on the places of Roma massacres in Ukraine. What kind of agents of memory are behind the numerous constructions of new memorials in Ukraine? Roma communities? The authorities? Ukrainian NGOs? Political parties? The European Union? Foreign funders?

The theoretical model for this article is based on the concept of "sites of memory" developed by Pierre Nora and Lawrence Kritzman. They argue that memory shapes the future by determining our attitude to the past, emphasising that crystallised memories are extremely powerful factors in the mobilization of an ethnic group and the strengthening of their identity. The sites of memory, considered by these scholars very broadly (that is, as images on banknotes or in movies), are an extremely powerful factor in the consolidation of a nation and

8 Andrej Kotljarchuk. "Palityka pamiaci u suchasnai Belarusi. Memaryialy druhoi susvetnai vainy i etnichnyia menshastsi krainy.” ARCHE 2 (2013): 173-194. 
mobilization of ethnic groups. The process of inclusion of an ethnic minority's collective memory into a national context takes place through sites of memory. ${ }^{9}$

The authorities are not interested strictly in history but in memory, which always has a strongly engaged political meaning. In this regard, it is important to trace the history of sculptural projects for public monuments that did not secure the approval of the authorities (in other words, failed the contest) and were never implemented. While history belongs to humanities, the science that associated with a critical understanding of past events through source criticism, memory is coupled with contemporary politics and the dedicated creation of a historical myth capable of uniting different ethnic and social groups in society.

Memorial politics crystallise in sites of memory, amongst which the most influential ones are monuments, because the physical space of memory is created through them, connecting a historical event, a remembrance day and the participants in the ceremony. ${ }^{10}$ The memorial gives sacral meaning to the landscape, which "helps to create the national iconography of a contemporary state". ${ }^{11}$ In a democratic state, memory politics are a common action field for the authorities and civil society that, in turn, have important leverage (independent media etc.). In a totalitarian state, the government has a virtual monopoly over public memory, deciding what to remember and what to forget. In such states, the inscription on a public monument must always be approved by the authorities and is the ultimate, canonised and embedded in concrete viewpoint of the official stand on events of the past.

The idea of raising monuments to the dead did not originate with WWII, but no other war has given birth to so many. A typical war memorial gives the following information: a short description and chronology of tragic events, the number or list of victims, information about the criminals and words addressed to the victims' descendants. Not only is the sculptural group important, but also the place chosen by the authorities for the monument (a central or marginal point of the cultural landscape). The language or languages of the monument play a

9 Pierre Nora and Lawrence Kritzman. Realms of memory: rethinking the French past. 1. New York: Columbia University Press, 1996; Realms of memory: rethinking the French past. 2. New York: Columbia University Press, 1997.

10 Nurit Schleifman. "Moscow's Victory Park: A Monumental Change.” History and Memory 13. 2 (2001): 5-34; Benjamin Forest and Juliet Johnson. "Unravelling the Threads of History: Soviet-Era Monuments and Post-Soviet National Identity." Annals of the Association of American Geographers 92.3 (2002): 524 - 547; Henry Pickford. "Conflict and Commemoration: Two Berlin Memorials.” Modernism modernity 12.1 (2005): 133-173.

11 Michaela Schäuble. "How History Takes Place: Sacralized Landscapes in the Croatian-Bosnian Border Region.” History and Memory 23.1 (2011): 24. 
major role. Thus, a language that the majority of the population does not understand refers to the ethnic meaning of the site of memory, even when ethnicity cannot be guessed directly. In most cases, an inscription in the language of a minority is accompanied by an inscription in the official language, which in the Post-Soviet monuments is Ukrainian.

\section{The Soviet period, 1942-1991}

The author believes that the comprehensive analysis of contemporary Ukrainian memory politics is not possible without an examination of the Soviet period. The theory of 'path dependence' is suitable for the analysis of contemporary memory politics with respect to WWII. In accordance with this theory, the scope and limitations of new politics (including memory politics) are determined by the political choices made or results attained much earlier by the previous political regime. $^{12}$

Information in the Soviet WWII media about the Nazi extermination of Roma was minimal. Roma were not mentioned (unlike Jews) in the well-spread widelydisseminated note on Babi Yar announced by Soviet Foreign Minister Vyacheslav Molotov on 6 January 1942. ${ }^{13}$ One can agree with Karel Berkhoff that the absence of significant foreign or domestic political factors was a main reason for the almost complete silence on the part of the Soviets about the killings of Roma by Nazis. He points out that "in the eyes of the Kremlin, Gypsies, who actually were subject to the same mass extermination as Jews [Stalin did know about Roma in 1943], had no political value". ${ }^{14}$

However, in some wartime publications the Soviet media stressed that the extermination of Roma by the Nazis was motivated exclusively by racial goals. In June 1944, the front correspondent of the leading military newspaper, Krasnaya Zvezda Ilya, Konstatinoskii published an article about the forced deportation to Transnistria of Romanian Roma by the regime of Ion Antonescu and also about their mass death on the Ukrainian steppes. ${ }^{15} 29$ August 1944 the largest

12 Stefan Hedlund. Russian Path Dependence. London: Routledge, 2005.

13 "Nota narodnogo komissara inostrannykh del SSSR tov. V. M. Molotova ot 6 ianvaria 1942 goda.” Nurnbergskii process. Sbornik materialov. Moscow: Gosudarstvennoe izdatel'stvo iuridicheskoi literatury, 1954, 515-516.

14 Karel Berkhoff. "Pogolovnoe unichtozhenie evreiskogo naseleniya. Holocaust v sovetskikh SMI, 1941-1945.” Holocaust $i$ suchasnist’ 1.7 (2010): 116.

15 Ilya Konstatinovskii. "Zemlia Moldavii.” Izvestia 137.8439 (10 June 1944): 3. 
Soviet newspaper, Izvestia, argued that the systematic destruction of Roma by Nazis was racially motivated: "With particular sadism and cruelty the Germans shot Gypsies, including women and children living in Vyborg, Pushkino and Novorzhev districts. All of them were shot just for the fact that they were Gypsies". ${ }^{16}$

After the war the exceptional nature of the systematic extermination of the Roma people was not recognised by the Soviet state. Soviet historians had created a huge historiography of what they termed the Great Patriotic War, without using the word Holocaust or the expression the genocide of Jewish and Roma peoples. The Soviet totalitarian regime kept silent about many aspects of the war. In addition to the Holocaust, there was little mention of crimes by Soviet partisans, the history of the non-Soviet Ukrainian partisan resistance, and the mass collaboration with the Nazi regime on the part of Russians and Ukrainians. During the Soviet era, the Nazi genocide of Roma was muted. The victory was seen to be achieved by all Soviet people, and the war was depicted as a tragedy for all Soviet peoples. Ignoring the ethnic background of the victims, the authorities persistently used a vague concept of "peaceful Soviet citizens" (mirnye sovetskie grazhdane). The key note of Soviet memory politics was heroisation. For Soviet leaders, this war was first of all a war of heroes: soldiers, partisans and members of the underground resistance. Thus hundreds of Roma and Jewish mass graves have remained unmarked or marked by simple, anonymous obelisks. Without having a public space, the collective memory of the Roma genocide continued, mainly in oral form in Romani family circles. ${ }^{17}$

The Soviet policy of forgetting can be described by the formulation of Karl Jaspers, who called the silence surrounding the Nazi past in Europe "aggressive". ${ }^{18}$ Those who tried to break taboos on memory were repressed. For example, in 1968 engineer Mikhailo Kochubievsky was arrested in Kyiv for talking with people in Babi Yar. Kochubievsky argued that "Babi Yar is not just a site for a nameless massacre of victims of fascism, but the largest place of genocide of the Jewish people". ${ }^{19}$ The struggle of the Jewish community and

16 "Soobshchenie Chrezvychainoi Gosudarstvennoi Komissii po ustanovleniu i rassledovaniu zlodeianii nemetsko-fashistskikh zakhvatchikov i ikh soobshchnikov.” Izvestia 205.8507 (29 August 1944): 3.

17 Michael Stewart. "Remembering without Commemoration: the Mnemonics and Politics of Holocaust memories among European Roma." Journal of the Royal Anthropological Institute 10.3 (2004): $561-582$.

18 Gilad Margalit. Germany and its gypsies: a post-Auschwitz ordeal. Madison: University of Wisconsin Press, 2002, 176.

19 Mikhail Mitsel. "Zapret na uvekovechivanie pamiati kak sposob zamalchivania Holocausta." Holocaust i suchasnist’ 1.2 (2007): 14. 
Soviet intelligentsia for recognition of the Jewish genocide led to some compromise with the government. In many cases (but not in Babi Yar), the inscription on the monuments in Russian during the Soviet era was translated into Yiddish. The letters of the Hebrew alphabet left no doubt about the ethnic origin of the victims. ${ }^{20}$

The lack of an educated Roma elite and the poor integration of Roma into Soviet society did not give Roma a chance for any recognition of their tragedy. Unlike the Jews, the Roma people did not have a political and cultural diaspora outside the Soviet Union or an independent state representing their ethnic community. The Great Soviet Encyclopaedia briefly informed its readers that "during the Second World War in 1939-45 twenty thousand Gypsies were brutally exterminated by the Nazis in Central and Eastern Europe". ${ }^{21}$ However, the number of victims was underestimated. In addition, the Soviet Union was not mentioned, and Nazi-occupied territory was not, according to the Great Soviet Encyclopaedia, a place of the massacre of Roma people. By 1991 there was not a single monument to the genocide of Roma in the Soviet Union. In contrast, by 2013, 113 places of mass extermination of Roma were identified on the territory of Ukraine; ${ }^{22}$ and 27 mass graves in Belarus. ${ }^{23}$ However, dozens of mass graves remain unknown or unmarked, many of which were destroyed in the course of construction and agriculture. ${ }^{24}$

\section{Ukraine's past dependence and contemporary problems of commemoration}

Memorialization of the victims of the Nazi genocide of the Roma in Ukraine faces a number of objective obstacles related to the Soviet period. One of the main problems of contemporary memory politics is the depersonalisation of the vic-

20 Mordechai Altshuler. "Jewish Holocaust Commemoration Activity in the USSR under Stalin.” Yad Vashem Studies 30 (2002): 221-240.

21 Tatiana Ventsel. “Tsygane.” Bolshaya Sovetskaya Enciklopedia. 28. Moscow, 1978, 606 607.

22 Peresleduvannia ta vbivstva romiv na terenakh Ukrainy u chasi druhoi svitovoi viini. Zbirnik dokumentiv ta spohadiv. Ed. Mikhail Tyaglyy. Kyiv: Ukrainian Centre for Genocide Studies, 2013. Table 2.

23 Kotljarchuk. "Palityka pamiaci u suchasnai Belarusi," 173-194.

24 Andrej Kotljarchuk. "Natsistskii genotsid tsygan na territorii okkupirovannoi Ukrainy: rol' sovteskogo proshlogo v sovremennoi politike pamiati.” Holocaust i suchasnist. 1.12 (2014): 24-50. 
tims of the Roma genocide. The Roma traditionally avoid contact with the authorities, and the official data and the real number of the Roma can differ greatly.

The number of Roma in 1941 on what is today the territory of Ukraine is unknown. The Soviet census of 1939 gives a figure of 10,443 Roma in Soviet Ukraine. However we know that the official census and the actual number of Roma differ significantly. For example, the All-Ukrainian census of 2001 counted 14,000 Roma in Transcarpathia. At the same time, the regional tax registration office listed 25,720 Roma in Transcarpathia, which is 55 per cent of all Ukrainian Roma. ${ }^{25}$ This of course makes no sense. The situation prior to WWII was even more complicated. The 1939 Soviet census did not include the Roma population in the Crimea, which became part of Ukraine in 1954. In addition, this census did not account for Roma in territories occupied by the Soviet Union during WWII: Polish Western Ukraine, Romanian regions of Northern Bukovina and Southern Bessarabia; and Transcarpathia, which before the war was an autonomous part of the Czech Republic and during the war was occupied by Hungary. These regions, which were settlement areas of the Roma population, were merged into Ukraine as a result of WWII.

Most Ukrainian Roma were nomadic before WWII and had no passports, and they avoided any contact with the authorities, including the census scribes. All this greatly complicates all possible calculations. Aleksandr Kruglov in his quantitative study of Roma genocide victims in Ukraine states that there were about 20,000 Roma on the territory of today's Ukraine at the beginning of WWII. The total number of victims among the Ukrainian Roma is estimated by him to be 19,000-20,000, of whom more than half were Romanian Roma deported to southern Ukraine. ${ }^{26}$ It should be also noted that agricultural and warm climate Ukraine was a traditional place for the summer migration of North-Russian, Belarusian and Baltic Roma agricultural workers. ${ }^{27}$ Researchers of the Roma genocide also point out that a significant number of mass graves of nomadic Roma remain unknown. Often the only witnesses were the perpetrators themselves. ${ }^{28}$ Due to the lack of reliable statistics on the size of the pre-war Romani population in the Soviet Union, Poland, Romania, and the Czech Republic, any exact figure

25 Materialy mizhnarodnoi tsyhanoznavchoi konferentsii Romy Ukrainy iz minulogo v maibutne. Kyiv: Justinian, 2008, 13.

26 Aleksandr Kruglov. “Genocide tsygan v Ukraine 1941 - 1944: statistiko-regional'nyi aspect.” Holocaust i suchasnist' 2.16 (2009): 86-113.

27 Ibid.

28 Nadezhda Demetr and Nikolai Bessonov, and Niklolai Kutenkov. Istoriya tsygan - novyi vzgliad. Voronezh: IPF, 2000. 217. 
of victims is questionable. A recent study estimates the number of the Roma genocide victims on the territory of Ukraine to vary from 26,000 to 62,500 , with the likely figure to be in excess of about $40,000 .^{29}$

De-personification of victims is another problem for memory work on the Roma Holocaust. It also highlights the difference between the memory of the Jewish and the Roma tragedy. The Jewish community already in the war years had made an effort to document the tragedy of Babi Yar. ${ }^{30}$ Some testimonies were published by Soviet war correspondents already during the war. ${ }^{31}$ The report Black Book, which was prepared by Vasily Grossman and Ilya Ehrenburg, was banned in the Soviet Union. However, in 1946, it was published in the USA and has been available to Western scholars and Soviet dissidents. ${ }^{32}$ In 1991, in Kyiv, the first memory book of the Jewish victims of Babi Yar was published. The first list of Jewish victims of Babi Yar was already prepared during the Soviet period and included more than 7000 names. ${ }^{33}$ A new list published later contains more than 14,000 names. ${ }^{34}$ The names of Roma victims of Babi Yar still are unknown.

A number of other factors distinguish the memory work in the Jewish and Roma tragedies. Unlike the Jews, the Roma to a great extent lack their own cultural landscape. If today the Jewish Holocaust is remembered, not only through monuments but also through deserted synagogues, the former Jewish ghettos and cemeteries, the Roma do not have any such cultural markers. With the genocide, almost all their physical space of memory was destroyed.

In addition, Ukrainian Roma have names and surnames which are typical for the local population (Ukrainian, Polish, Russian, Hungarian and Romanian). The role of anthroponomy is important. When the protocols of the Soviet Extraordinary Commission for Investigation of War Crimes (ChGK) do not specify the ethnic origin of the victims, it is still possible to identify Jewish victims by analysing names. This is impossible in case of Roma victims.

29 Andrej Kotljarchuk. "Nazi Genocide of Roma in Belarus and Ukraine: the significance of census data and census takers." Etudes Tsigane 1 (2015).

30 Jeff Mankoff. "Babi Yar and the struggle for memory, 1944-2004," 393 -415; Arno, Lustiger. Stalin i evrei: Tragicheskaia istoriya Evreiskogo antifashistskogo komiteta i sovetskikh evreev. Moscow: Rosspen, 2008.

31 Aleksandr Avdeenko and Petr Olender. "Babi Yar.” Krasnaya Zvezda 274.5645 (20 November 1943): 3; Vasily, Grossman. "Doroga na Berlin.” Krasnaya Zvezda 38.6026 (15 February 1945): 3.

32 The Black Book: the Nazi crime against the Jewish people. Published by the Jewish Black Book Committee, New York: Duell, Sloan and Pearce, 1946.

33 Ilya Zaslavskii. Ed. Kniga Pamiati. Imena pogibshikh v Bab'em Yaru. Kyiv: Oberih, 1991. 34 Ilya Levitas. Ed. Babi Yar: Kniga pamiati. Kyiv: Stal, 2005. 
In most cases, the Roma were executed at sites, which were chosen by the Nazis for the extermination of the Jewish population, POWs and partisans. Such sites were usually classified by the Extraordinary Commission for Investigation of War Crimes and marked. None of the monuments, however, referred to the Roma victims of genocide. In post-Soviet Ukraine in many such places new monuments have been erected that this time emphasise the ethnicity of the genocide victims. For example the new Roma memorials at Babi Yar, Pirohova Levada, Koziatyn, Ostroushki and Odessa were designed on this basis.

A further difference between Jews and Roma in Ukraine is that, unlike Ukrainian Jews, Roma are not a homogeneous ethnic group. The Romani community of Ukraine is divided into a number of cultural and religious groups. Among them are Protestants, Orthodox Christians, Muslims, and Catholics. There are more than ten dialect groups of Roma in Ukraine, each using different Romani dialects as well as different languages in everyday life (Ukrainian, Russian, Romanian, Hungarian, Slovak, etc). Relations between different groups of Roma are not always close. ${ }^{35}$ Until 1956 the majority of Ukrainian Roma were nomadic. This means that often the emotional (family) link between the Roma community and local Holocaust mass graves is missing. This is precisely the situation in Torchyn, Ostroushki, Vilshanka and many others places. For instance an unknown group of Roma were killed by Nazis near the west Ukrainian town of Torchyn. However, the local Romani community is represented today by Romanian Roma, the survivors and descendants deported to southern Ukraine. They lived after the war in Transnistria and moved to Torchyn in 1956 after the Soviet Act of Settlement of all Nomadic Gypsies. As a result the Roma of Torchyn remember well the mass deaths of their deported ancestors in southern Ukraine, but know nothing about the local massacre, which were observed during field studies (interviews recorded in the author's archives). This situation is typical. Coupled with the lack of educated strata among the Roma, this means that the Ukrainian Roma themselves cannot usually be active agents of memory. This is why, in contrast to the Jewish situation, the localization of mass graves and initiatives to raise monuments have come mostly from the non-Romani NGOs and the Ukrainian government.

According to the 2004 resolution of the Ukrainian parliament, an International Remembrance Day of the Holocaust of the Roma is held annually on 2 Au-

35 Lev Cherenkov. “Tsyganskaya dialektologiya v Ukraine. Istoriya i sovremennost.” Materialy mizhnarodnoi tsyhanoznavchoi konferentsii Romy Ukrainy iz minulogo v maibutne. Kyiv: Justinian, 2008: 161-172. 
gust and local authorities have to erect memorials on the places of mass executions in order to commemorate the genocide. ${ }^{36}$ As a result more than 20 monuments commemorating Roma victims of the Nazi genocide have been erected in Ukraine since 2005.

The case of Babi Yar (or Babyn Yar in Ukrainian, means Old Woman's Ravine) is considered to be the single largest massacre in the history of the Holocaust and has become a central symbol of the Nazi genocide on the occupied Soviet territory. While in some regions of Ukraine the active process of commemoration of Jewish and Roma Holocaust mass graves is going on, in the capital conflict over memory continues. ${ }^{37}$

Babi Yar is a chain of seven deep ravines in the north-western suburb of Kyiv. There on 29-30 September 1941, nine days after the German occupation of the city began, more than 33,000 Jewish civilians were exterminated by the Nazis in two days of mass killings. Near Babi Yar the Lukianivka railway goods station is situated and Jewish victims who were forced to assemble there believed that the Nazis were going to deport them from Kyiv to another place. The total number of people murdered in Babi Yar between 1941 and 1943 (Jews, Roma, Soviet POWs and underground fighters, the mentally ill, Ukrainian nationalists, civilians) is estimated to be about 100,000. ${ }^{38}$ Executions of Roma in Babi Yar by the Nazis continued until the liberation of the city by the Red Army in November $1943 .{ }^{39}$ According to Anatoly Kuzntesov the mass killings of Jews and Roma caused alarm among the ethnic Ukrainian majority. "Jews kaput, Gypsies too, and then Ukrainians, then come you" - was a popular saying in Kyiv during the war. ${ }^{40}$

During the war the Jewish tragedy of Babi Yar was reported in Soviet media. ${ }^{41}$ The massacre of Jews was mentioned in a diplomatic note by Foreign Minister Vyacheslav Molotov on 6 January 1942 entitled On the widespread robbery, devastation of the population, and the atrocities of the German authorities on

36 On the night of 2 August 1944 the so-called Zigeunerlager in Auschwitz-Birkenau was eliminated by the Nazis. In 2002 this day was proposed by the Council of Europe as International Roma and Sinti Genocide Remembrance Day.

37 Burakovsky. "Holocaust remembrance in Ukraine." 371-389; Ingmar Oldberg. "Both victims and perpetrators. Ukraine's problematic relationship to the Holocaust." Baltic worlds 4.2 (2011): $40-43$.

38 Karel Berkhoff. Babi Yar: Site of Mass Murder, Ravine of Oblivion. Washington: United States Holocaust Memorial Museum, 2012.

39 Aleksandr Kruglov. Sbornik dokumentov i materialov ob unichtozhnenie natsistami evreev Ukrainy $v$ 1941-44. Kyiv: Institut Judaiki, 2002, 78.

40 Anatoly Kuznetsov. Babi Yar. Roman-dokument. Frankfurt am Main: Posev, 1970, 157.

41 Mankoff. "Babi Yar and the struggle for memory, 1944-2004," 393-415. 
the occupied territories of the Soviet Union, and published in 1942 by the leading newspaper Pravda. ${ }^{42}$ Nation-renowned war correspondents Vasily Grossman, Aleksandr Avdeenko and Petr Olender also published testimonies about the mass killings of Jews in Babi Yar in 1943-1945. ${ }^{43}$ However, the mass murder of Roma in Babi Yar was not mentioned.

On 29 February 1944, Soviet media published the Extraordinary Commission for Investigation of War Crimes in Kyiv, a report led by Nikita Khrushchev. The Commission's report did not specify the ethnicity of the victims and muted the racial character of the mass killings, noting that: "In Babi Yar over 100,000 Soviet citizens were killed, women, children and old folk". ${ }^{44}$ The decision of the Communist Party's leadership to ignore the racial and genocidal nature of the massacre in Babi Yar was crucial for the Soviet policy of forgetting the Jewish and Romani Holocausts. The decision was taken despite the Soviet leadership's knowledge of the results of investigation by Extraordinary Commission for Investigation of War Crimes, which contained detailed information on the mass murder of Roma in Babi Yar. A major witness, a professor at the Kyiv Institute of Forestry Ivan Zhitov, stated that the Germans killed Roma in Babi Yar three months after the Jewish massacre, meaning at the end of December $1941 .{ }^{45}$ A local woman, L. I. Zavorotnaya-Grigurno stated that "Roma were shot at the Babi Yar massacre later than the Jews". She stated that "during the war she saw several gypsy wagons with people drove past her house by Nazis towards Babi Yar”. One of the witnesses, N. Tkachenko, claimed to see Romani clothes left after the killings in Babi Yar. ${ }^{46}$ Until 1991 none of the testimonies were available for research, making it impossible to study the mass murder of Roma in Babi Yar. However, despite the lack of available written sources, the extermination of

42 "Nota narodnogo komissara inostrannykh del SSSR tov. V. M. Molotova ot 6 ianvaria 1942 goda." Nurnbergskii process. Sbornik materialov. Moscow: Gosudarstvennoe izdatel'stvo iuridicheskoi literatury, 1954, 504-517.

43 Avdeenko and Olender. "Babi Yar." 3; Grossman. "Doroga na Berlin," 3.

44 "Soobshchenie Chrezvychainoi Gosudarstvennoi Komissii po ustanovleniu i rassledovaniu zlodeianii nemetsko-fashistskikh zakhvatchikov i ikh soobshchnikov o razrusheniyakh I zverstvakh sovershennykh nemetsko-fashistskim zakhvatchikami v gorode Kyive.” Izvestia 50.8352 (29 February 1944): 3.

45 "Svidetel'stvo zhitelei goroda Kieva khudozhnika Nikolaya Adrianovicha Priakhova i professora Ivana Nikolaevicha Zhitova i drugikh o massovykh rasstrelakh v Bab'em yaru.” Central State Archive of the supreme power and administration of Ukraine (TsDAGO). Fond R- 4620, opis 3, sprava 243a, list 38.

46 Vitalii Nakhmanovich. "Rasstrely i zakhoroneiya v raione Bab'ego Yara vo vremia nemetskoi okkupatsii goroda Kyiva 1941-43.” Babi Yar: chelovek, vlast', istoriya. Dokumenty i materialy. Kyiv, 2004, 84-163. 
Roma in Babi Yar was a well-known oral history for the residents of post-war Kyiv. In the famous book Babi Yar: A Document in the Form of a Novel (1966) Anatoly Kuznetsov, who grew up in Kyiv noted:

The fascists hunted Gypsies as if they were game. I have never come across anything official concerning this, yet in the Ukraine the Gypsies were subject to the same immediate extermination as the Jews ... Whole tribes of Gypsies were taken to Babi Yar, and they did not seem to know what was happening to them until the last minute. ${ }^{47}$

In April 1945 Pravda informed the Soviet people about the decision of the government of Ukraine to build in Babi Yar a memorial and a museum "to the memory of ten of thousand residents of Kiev". ${ }^{48}$ Despite the announcement there were no monuments in Babi Yar until 1976 and the site was unmarked until 1966. Thus, 19 September 1961 Yevgeny Yevtushenko, the renowned Russian poet, published the epic Babi Yar in Literaturnaya gazeta, the leading periodical of the Union of Soviet Writers. The poem, whose first line is "Over Babi Yar there are no monuments" became a strong public protest against the government's refusal to recognise Babi Yar as a Holocaust site. ${ }^{49}$ In March 1963 at a meeting with Soviet writers Nikita Khrushchev, the leader of the country and the former head of Ukraine and the ChGK on Babi Yar, devoted special attention to Yevtushenko's poem. According to Khrushchev "the author of the poem showed an ignorance of historical facts, he believes that the victims of Nazi atrocities were only the Jews, in fact there [in Babi Yar] were murdered many Russians, Ukrainians and other Soviet people of various nationalities".50

In 1966 Anatoly Kuznetsov's documentary novel, Babi Yar, was published in the Soviet Union in censored form in the monthly literary magazine Yunost'. Moreover, the next year the novel was printed in 150,000 copies by the Komsomol publishing house Molodaya gvardiya. ${ }^{51}$ It should be note that fragments concerning the genocide of Roma were kept in the text. The novel was highly criticised by the leading Soviet newspaper Izvestia, ${ }^{52}$ and both the book and the monthly literary magazine were confiscated from all Soviet libraries. The totalitarian regime ordered the silencing of the tragedy of Roma, an order which was

47 Anatoly Kuznetsov. Babi Yar. A documentary novel. New York: The Dial Press, 1967.

48 “Pamiatnik pogibshim v Bab’em Yaru.” Pravda (3 April 1945): 3.

49 Zvi Gitelman. "Politics and the historiography of the Holocaust in the Soviet Union." Bitter legacy: confronting the Holocaust in the USSR. Ed. Zvi Gitelman. Bloomington: Indiana University Press, 1997, 20.

50 “Rech’ tovarishcha N. S. Khrushcheva.” Pravda 89 (10 March 1963): 1, 4.

51 Anatoly Kuznetsov. Babi Yar. Roman-dokument. Moskva: Molodaya gvardiya, 1967.

52 P. Troitskii. "Po stranitsam zhurnalov.” Izvestia 19.15413 (20 January 1967): 5. 
carefully followed by Soviet officials, historians and media. Moreover the Soviet leadership, who long sought to monopolise the collective memory of the war, left Babi Yar out of the official war narrative, and even sought to eradicate the site of memory physically. On 13 March 1961 as the result of an accident at the Kurenivka brick factory near Babi Yar, the dam securing the loam pulp failed after rain, releasing large volumes of pulp down to Babi Yar.

On 29 September 1966 on the $25^{\text {th }}$ anniversary of the tragedy, an unauthorized rally in Babi Yar was held for the first time in the Soviet era. The participants demanded the recognition of the Jewish genocide and the construction of a monument at Babi Yar. The rally was attended by famous Soviet writers and dissidents among them Viktor Nekrasov, Boris Antonenko-Davidovich, Ivan Dziuba, Petr Yakir, Sergei Paradzhanov, Vladimir Voinovich and Sergei Dovlatov. However, the Roma tragedy was not discussed. ${ }^{53}$ Soviet authorities gave in to the pressure of civil society and in 1966 a foundation stone was placed in Babi Yar with the inscription in Russian: "There will be erected a monument to the Soviet people - victims of fascist crimes in the period of temporary occupation of Kyiv in 1941-1943”. Finally in 1976 a typically Soviet monument in heroic style was erected at the Babi Yar site with the inscription in Russian: "Soviet citizens, POWs, soldiers and officers of the Red Army, were shot here in Babi Yar by German Fascists". ${ }^{54}$ Despite the silence on the Holocaust, the memorial legitimised the practices of memory. Every year, on 29 September the monument has been visited not only by Jews but also by local Roma. It was during these years that the Romani tradition was born to bring to the monument the photos of relatives murdered by the Nazis. ${ }^{55}$ This practice continues to this day. By this ceremony the Roma community is trying to overcome the problem of de-personalization.

The Soviet policy of forgetting complicated the contemporary documentation of the Roma genocide. The result of this long-term government policy was the depersonification of victims of the Roma genocide. As a result, it remains unknown when, how many, and what groups in Babi Yar of Roma were killed. Roma of Kyiv state that their relatives were shot in Babi Yar in $1941 .{ }^{56}$ The archival sources support their testimonies. In 1937, a Romani craft cooperative, Trudnatsmen, was established in Kurenivka near Babi Yar that united 27 Roma families. In 1941 an administrative building for the Romani cooperative was situated in Babi Yar in the former NKVD shooting range. There is no evidence about the existence of Ro-

53 Rafail Nakhmanovich. "Babi Yar-1966: kak eto bylo.” Maidan 28 September 2006.

54 Tatiana Evstafieva. "Babi Yar vo vtoroi polovine XX veka." Babi Yar: chelovek, vlast', istoriya. Dokumenty i materialy. Kyiv: Vneshtorgizdat, 2004, 187-206.

55 Kotljarchuk. "Natsistskii genotsid tsygan na territorii okkupirovannoi Ukrainy," 24-50. 56 Ibid, 24-50. 
mani craft cooperative in Kyiv after WWII. ${ }^{57}$ However, neither scholars nor Roma of Kyiv are able to compile a list of the victims.

With glasnost and perestroika, new interpretations developed in Ukraine regarding the significance of the Roma and Jewish victims of the Nazi occupation. The Soviet monopoly on memory ended and the significance of the Roma genocide underwent a substantial change. After the collapse of the Soviet Union, the government of independent Ukraine allowed in 1991 the establishment of a new memorial at Babi Yar, specifically identifying the victims as Jewish and Roma. In 1989 the Soviet monument was completed; however, the plaques in Yiddish and Russian only provided information about the Jewish genocide. On September 29, 1991 on the $50^{\text {th }}$ anniversary of the tragedy, the Jewish memorial Menorah was opened in Babi Yar. In 1992, a monument to Ukrainian nationalists was erected. For the last decade a number of monuments have been built in Babi Yar devoted to the memory of murdered children, the mentally ill, POWs, Soviet underground fighters, Orthodox priests, and Ukrainian nationalists, Ostarbeiters, Dynamo Kyiv football players and victims of the Kurenivka accident of 1961. As a result a competition of victimhood was created in Babi Yar. The Roma memorial is still under construction.

In 1995, an initiative to erect a Roma monument in Babi Yar was taken by the sculptor Anatoly Ignashchenko (1930-2011). One of the most famous Ukrainian sculptors and half-Roma by origin, Ignashchenko is the producer of more than 200 monuments around the world. He was also the chief-sculptor of a Soviet monument in Babi Yar. Ignashchenko admitted that an idea to raise a monument at Babi Yar came to him after talking with Romani activists Mikha Kozimirenko and Vladimir Zolotarenko.. ${ }^{58}$ In 1996 Ignashchenko produced a model of the monument, which was a gypsy wagon made of wrought iron. The author came up with an original solution to overcome the de-personification of victims. He attached to the tent photo frames in which relatives are encouraged to insert photos of victims. The inscription on the monument was completed both in Ukrainian and Romani: "To the memory of Roma exterminated by the Nazis in 1940 - 1945. We remember!”

Roma activists, students and members of the Catholic Community in Kyiv participated in fundraising for the monument and in volunteer work in Babi Yar. The monument was completed, and the ground prepared in 1997. However, in the end, the raising of the monument was forbidden by City architect Serhij

57 State Archives of the City of Kyiv (DAMK). Fond R-1, opis 1, sprava 10715.

58 Vladimir Platonov. "Babiy Yar: Tragedia o tragedii." Zerkalo Nedeli 39 (1997); Serhii Yarmoluk. “Kvitok do Romanistana.” Den’ 30 May 1998; Natalia Zinchenko. "Baron i kosmos.” Aratta 17 February 2009. 
Babushkin with the motivation that it did not fit with the general design of the Babi Yar memorial. As a result the monument was transported to western Ukraine and awarded to the town of Kamyanets-Podilsky.

On 29 September 1999 at the cost of Roma organizations a simple foundation stone was put in Babi Yar with an inscription in Ukrainian: "In this place will be build a memorial to the victims of the Roma Holocaust". On the night of 4 July 2011, a few weeks before the International Day of the Roma Holocaust, a foundation stone dedicated to the Romani victims was vandalized. On 13 July 2011 the Roma Congress of Ukraine sent an open letter of protest to Prime Minister Mykola Azarov, who was the chair of the committee for the $70^{\text {th }}$ anniversary of Babi Yar. Roma called for an end to "the discrimination of their memory by the state" and required the inclusion of Romani representatives in the committee and dialogue with the government regarding the construction of a memorial in Babi Yar. ${ }^{59}$ In 2012 a new foundation stone was built on the same site, this time sponsored by the state. A new inscription in Ukrainian appeared: "In memory of the Roma who were shot in Babi Yar". Romani activists point out the inscription can be interpreted as a final version of the monument. Romani activists are outraged by the fact that they have been waiting almost 25 years for a memorial in Babi Yar while a number of other memorials have been built during this period of time. ${ }^{60}$ Monuments dedicated to various groups of victims are scattered in different places in Babi Yar at a considerable distance from each other. There is neither a central memorial for all groups of victims, nor a museum. The existing public map of Babi Yar is not easily accessible and to find the Roma memorial stone is rather difficult.

The creation in 2007-2012 of the public agency the National Historical Memorial Preserve Babyn Yar is an important stage in the Ukrainian politics of memory. ${ }^{61}$ This agency is responsible for the development of the memorial site. The staff of The National Preserve organizes a ceremony on the International Day of the Roma Holocaust and informs the public about the Remembrance Day on their Webpage. On 12 April 2012 the "Concept of development of the National Historical Memorial Preserve” was approved by the Ukrainian government. The

59 "Romi vimahaut'vid Azarova vshanuvaty i ikhni Holocaust." Ukrains'ka Pravda 13 July 2011.

60 Kotljarchuk. "Natsistskii genotsid tsygan na territorii okkupirovannoi Ukrainy," 24-50.

61 Decree 308 of the Cabinet of Ministers of Ukraine On the establishment of Memorial Reserve Babyn Yar, 1 March 2007. http://www.kby.Kyiv.ua/komitet/ru/documents (22 October 2014); Decree 258/2010 of the President of Ukraine Viktor Yushchenko about the National status of Memorial Preserve Babyn Yar. http://www.kby.Kyiv.ua/komitet/ru/documents (22 October 2014). 


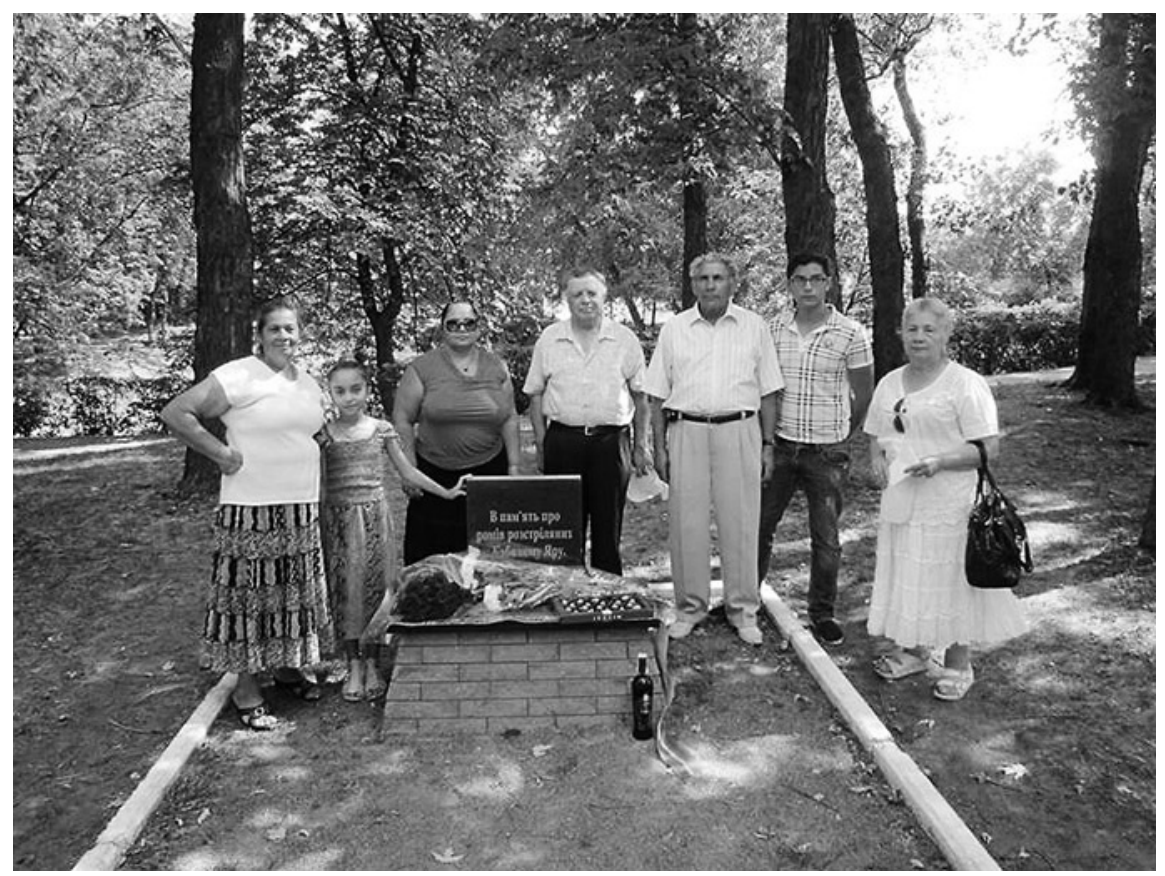

Fig. 1: Romanis at the foundation stone in Babi Yar on the International Roma Genocide Remembrance, 2012. Photo by Andrej Kotljarchuk.

curator of a new memorial project is Larysa Skoryk. ${ }^{62}$ She is a renowned architect and a producer of Bykivnia Graves - a National memorial dedicated to the victims of Stalin's terror.

Despite all the conflict over the past, Babi Yar is step by step becoming a national pantheon of all the groups of Nazi victims. Today this place is regularly attended by Romani activists, official Ukrainian and foreign delegations. The Roma tragedy of Babi Yar is well represented in the media space of Ukraine. A simple Google search gives over 15 thousand references to the phrase "Babi Yar and Roma” in Ukrainian. However when in August 2001, Pope John Paul II visited Babi Yar he did not mention the Nazi atrocities committed against the Romani victims of the genocide in his speech. Actually the ex-president of Ukraine, Viktor Yushchenko, is the only head of state who frequently mentioned

62 Official website of Larysa Skoryk. http://www.skoryk.net.ua/sakralna-arhitektura-mon umenty/babyn-yar (22 October 2014). 
the Roma tragedy of Babi Yar and issued a special statement on the memory of the Nazi genocide of Roma people. ${ }^{63}$

\section{Recent trends in commemoration politics}

Andrii Portnov argues that humanization is the basic strategy of contemporary Ukrainian memory politics regarding WWII, a switch from the memory of heroes to the memory of the suffering of ordinary people. ${ }^{64}$ Topics prohibited during Soviet times such as the Holocaust, the Ukrainian Insurgent Army (UPA), and the Ukrainian-Polish ethnic cleansings in Volhynia became themes for public debates. In 2003, 60 years after the ethnic cleansing in Volhynia, 59 prominent Ukrainian intellectuals wrote an open letter "Open Wound of Volhynia”. Public debates were initiated and on 11 July 2003, the presidents of Poland and Ukraine, Aleksander Kwasniewski and Leonid Kuchma, inaugurated in the village of Pavlivka/Poryck the first monument of reconciliation. ${ }^{65}$

New trends created opportunities for inclusion of the Roma collective trauma into the national context. The 2004 parliament's resolution certainly gave a powerful impetus to the memory work. In particular the parliament instructed the "Cabinet of Ministers of Ukraine, together with local authorities to identify mass graves and to investigate Hitler's ethnocide of Roma during WWII, in order to commemorate deported and executed representatives of this national minority". ${ }^{66}$ Indeed, since 2005 the Ukrainian government has supported a number of Roma Holocaust memory projects. ${ }^{67}$

Another strong argument for the intensification of memory work is the integration of Ukraine into the EU. ${ }^{68}$ The European Commission against Racism and Intolerance (ECRI) continuously monitors the implementation of the 2004 parliamentary resolution in order to determine the extent of actual implementation of

63 "Address of the President of Ukraine Viktor Yushchenko devoted to the International Day of the Roma Holocaust.” Forum Natsii 8.87 (2009): 11-12.

64 Andrii Portnov. "Uprazhneniya s istoriei po-ukrainski.” Ab Imperio. 3 (2007): 13.

65 Yaroslav Hrytsak. Strasti za natsionalizmom. Kyiv: Krytyka, 2004, 126-137; Alexander Osipian. "Ethnic Cleansings and Memory Purges: The Ukrainian-Polish Borderland in 1939-1947 in Modern Politics and Historiography." Ab Imperio 2 (2004): 297 - 328.

66 "Resolution 2085-IV of the Verkhovna Rada of Ukraine on the International Day of the Roma Holocaust."Vidomosti Verkhovnoi Rady Ukrainy. 2 (2005): 65.

67 Tatiana Gabrielson. Propaganda of Romani Culture in Post-Soviet Ukraine. Unpublished PhD dissertation. The University of Texas at Austin. 2006, 127-132.

68 Anders Nordström. The interactive dynamics of regulation: exploring the Council of Europe's monitoring of Ukraine. Stockholm: Stockholm University Press, 2008, 221-229. 
the program of commemoration of the Roma genocide. ${ }^{69}$ Ukraine is a member of the EU program "Roma Decade 2005-2015". Following many European countries, Ukraine abandoned the official use of the word 'Gypsies' in favour of the more politically correct name 'Roma'. As known this term was recommended by the First World Congress of Roma in London in 1971. Today Ukraine is the only country in post-Soviet space that has replaced the official nomenclature, using 'Roma' in official documentation and media. Substantial support to commemoration projects in Ukraine has been given by foreign institutions, in particular the German Federal Foundation for Remembrance, Responsibility and the Future, the Friedrich Ebert Foundation and the George Soros Foundation "Renaissance”. The Soros Foundation has a special Roma of Ukraine Program, which has supported exhibitions on the memory of the Roma genocide, scientific conferences, and publication of documents. In order to overcome the de-personification problem the Romani organization of Odessa signed in 2011 an agreement with the oblast archives of Odessa. The intended result of the cooperation is to produce a memory book with a list of Romanian Roma deported to Transnistria. A number of scientific conferences on the genocide of Roma people held in Ukraine was organized by the Ukrainian Centre for Holocaust Studies, which also accumulated a considerable bibliography. ${ }^{70}$ Recently the All-Ukrainian Association of Teachers of History published with the financial support of the EU a textbook for secondary schools. A chapter of the textbook is about the Nazi genocide of Ukrainian Roma. As usual the link between the Nazi genocide, Axis powers and Ukrainian collaborators is missing and all responsibility is placed exclusively on the Germans. ${ }^{71}$

There is one more difference between the memorialization of Roma and Jewish mass graves. Monuments to the Jewish Holocaust are usually funded from abroad with the assistance of local Jewish communities. The Roma Holocaust memorials as a rule are initiated and funded by Ukrainian NGOs and local organizations. In Vilshanka (Poltava region), it was the local Cossack organization; in Pirohova Levada (Pyriatyn, Poltava region) - a local historical association, district authorities and private persons; in Kozatyn (Vinnitsa region) - a local veteran's organization, the Communist Party of Ukraine, the municipality, a subsidiary of the Ukrainian Railways; in Ostroushki (Sumy region) - the village administration and private persons. The contemporary memorial work is carried

69 Stan dotrimannia Ukrainoiu evropeiskikh standartiv $z$ prav $i$ svobod ludyny. Kyiv: Verkhovna Rada Press, 2010, $163-164$.

70 Kotljarchuk. "Natsistskii genotsid tsygan na territorii okkupirovannoi Ukrainy," 24-50.

71 Petro Kendzior, Ed. Razom na odnii zemli. Istoriya Ukrainy bogatokul'turna. Lviv: ZUKTs, 2012. 
out by a wide variety of different mainly non-Roma actors. Only three out of twenty memorials were initiated and partly funded by Romani organizations. New memorials on the places of mass executions of Roma are often motivated by the example of the capital. Thus, at the opening ceremony of 2011 in Ostroushki the deputy head of Sumy oblast Oleg Boyarintsev said: "the place where they were killed, thousands of our countrymen should be known by everyone in the Sumy region. Ostroushki is our Babi Yar". ${ }^{72}$

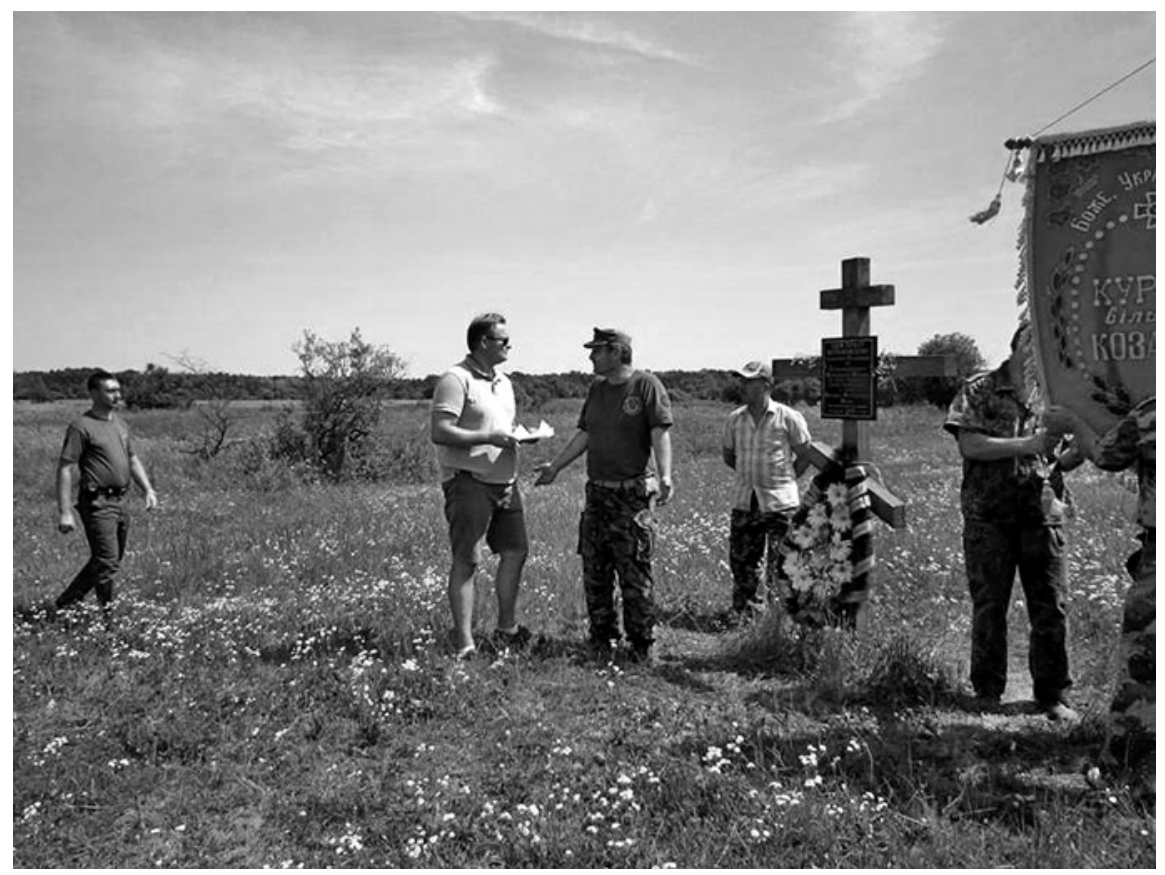

Fig. 2: The Cossacks of Lubny and the author at Roma Holocaust Memorial Cross in Vilshanka (Lubny district). 2012. Photo by Vadim Udod.

Today Ukraine shares with Germany the honorary first place in Europe regarding the number of Roma genocide memorials. However, a number of problems remain. Not all local authorities have implemented the 2004 decision of parliament. There are a number of regions (for example Crimea) where the International Day of the Roma Holocaust does not give a rise to any commemoration efforts. On 2 August the central TV channels of Ukraine did little to recall the

72 Official News Portal of Sumy region. http://sumyinfo.com (22 October 2014). 
tragedy of the Roma people. Some new genocide memorials (for example in Malyn and in Kopyli) despite the available data include no reference to the victims of Romani origin. As Michael Tyaglyi states the genocide of Roma is still considered by the researchers as "a second-class genocide which is located on the periphery of contemporary Ukrainian historical research". ${ }^{73}$

Differences at the local level are significant but inexplicable. In Mykolaiv, Odessa and Lutsk regions, exhibitions dedicated to the genocide of Roma were held, International Remembrance Day celebrated and new memorials erected. In Mykolaiv the local authorities involved non-Romani pupils in the memory work. ${ }^{74}$ At the same time in the eastern autonomous republic of Crimea, occupied in 2014 by Russia, despite many identified mass graves of Roma victims, there are still no monuments on places of mass executions indicating that the victims are of Roma origin and the Remembrance Day is not celebrated.

An acute problem is that a large number of Roma genocide mass graves remain unmarked. They are situated in remote rural areas (for example in Kysylyn, Lutsk region), which was not mentioned by the Extraordinary Commission for Investigation of War Crimes. Because of the privatization and high cost of agricultural lands, only memorialization can preserve unmarked graves from destruction. Today many mass graves are preserved by the owners of lands representing the older generation- the last witnesses of the genocide. That is the case in Ratne.

\section{Conclusion}

Post-Soviet Ukraine is a region of dynamic politics of the commemoration of the victims of the Roma Holocaust. The country is actively constructing a unifying model of collective memory capable of integrating all minority groups into a single national project. It is important to stress that the Roma Holocaust memorials are being built in both in the Western and Eastern parts of the country.

The major reasons for the intensification of memory work on the Roma Holocaust in Ukraine are:

- A new official strategy regarding the memory of WWII.

73 Mikhailo Tyaglyy. "Babyn Yar yak mistse masovogo vynishchennia ukrainskikh romiv: typova model?” Unpublished paper presented on the international conference Babi Yar: mass killings and its memory. Kyiv, 25 October 2011.

74 Olena Hrynevich. "Romi Ukrainy i Mikolaevshchyna.” Naukovi zapiski. Zbirnik prats molodikh vchenikh ta aspirantiv. Kyiv: National Academy of Sciences, 2008, 136-145. 
- A higher level of democratization in comparison with neighbouring Russia and Belarus.

- A process of integration into the EU, leading to some adjustments of the Ukrainian memory politics to comply to European standards.

The revising of the Soviet myth of WWII opened the once closed floodgates of memory. Fast-paced memorialization of the Roma genocide confirms the fact that the realignment of Soviet history around new narrative axes is taking place in the memory politics of today's Ukraine. For a long time the Roma minority was not included in Ukrainian nation building. The commemoration of the Roma Holocaust has the possibility to change this situation, boosting the inclusion of Roma in contemporary Ukrainian society. In the situation of the absence of a native Romani state, common territory, language, culture and religion, a shared memory of the genocide brings together different groups of Roma, mobilizing their national movement. As Slawomir Kapralski points out:

Romani Holocaust is already the main element of the Roma identity and the centre piece of their historical memory. Through the rituals of remembrance Roma focus on their common past in order to create a better future. ${ }^{75}$

The problems related to commemoration of the genocide of the Roma on the territory of Ukraine are limited, as this study confirms, mainly by the 'path dependence' factor and not by deliberately discriminatory politics towards the Roma minority.

\section{References}

Achim, Viorel. The Roma in Romanian history. Budapest: Central European University Press, 2004.

Adam, Zeikan and Elena Navrotska. Bilii kamin' z chornoi kativni. Holocaust romiv Zakarpatti, Uzhhorod: Uzhorods'ka miska drukarnia, 2006.

"Address of the President of Ukraine Viktor Yushchenko devoted to the International Day of the Roma Holocaust." Forum Natsii 8.87 (2009): 11-12.

All-Ukrainian census of 2001. http://2001.ukrcensus.gov.ua (22 October 2014).

Altshuler, Mordechai. "Jewish Holocaust Commemoration Activity in the USSR under Stalin." Yad Vashem Studies 30 (2002): 221-240.

Avdeenko, Aleksandr and Petr Olender. "Babi Yar." Krasnaya Zvezda 274.5645 (20 November 1943): 3.

75 Kapralski. "Symbols and Rituals in the Mobilisation of the Romani National Ideal," 77. 
Babi Yar: Kniga pamiati. Ed. Ilya Levitas. Kyiv: Stal, 2005.

Bartosz, Adam.Tabor Pamieci Romow. Tarnow: Regional Museum of Tarnow Press, 2003.

Bartov, Omer. Erased: vanishing traces of Jewish Galicia in present-day Ukraine. Princeton: Princeton University Press, 2007.

Belikov, Oleksandr. "Derzhavna politika stosovno tsygan Ukrainy: istoria i suchasnist." Naukovi zapiski. Zbirnik prats molodikh vchenikh ta aspirantiv. Kyiv: National Academy of Sciences, 2008. 24-56.

Berkhoff. Karel. Babi Yar: Site of Mass Murder, Ravine of Oblivion. Washington: United States Holocaust Memorial Museum, 2012.

Berkhoff, Karel. "Pogolovnoe unichtozhenie evreiskogo naseleniya. Holocaust v sovetskikh SMI, 1941-1945." Holocaust i suchasnist' 1.7 (2010): 62-122.

Bessonov, Nikolai. Tsyganskaia tragediia 1941-1945. Fakty, dokumenty, vospominaniya. Vooruzhennyi otpor. Sankt Petersburg: Shatra, 2010.

Bessonov, Nikolai. "Tsygane SSSR v okkupatsii. Strategii vyzhivaniia." Holocaust $i$ suchasnist'. 2:6 (2009): 17-52.

Björklund, Bengt. “Romska massgravar i Ukraina.” E Romani Glinda. 5 (2010): 12-18.

Burakovsky, Aleksandr. "Holocaust remembrance in Ukraine: memorialization of the Jewish tragedy at Babi Yar." Nationalities Papers 39.3 (2011): 371-389.

Cherenkov, Lev. "Tsyganskaya dialektologiya v Ukraine. Istoriya i sovremennost." Materialy mizhnarodnoi tsyhanoznavchoi konferentsii Romy Ukrainy iz minulogo v maibutne. Kyiv: Justinian, 2008: 161-172.

Decree 308 of the Cabinet of Ministers of Ukraine On the establishment of Memorial Reserve Babyn Yar, 1 March 2007. http://www.kby.Kyiv.ua/komitet/ru/documents (22 October 2014).

Decree 258/2010 of the President of Ukraine Viktor Yushchenko about the National status of Memorial Preserve Babyn Yar. http://www.kby.Kyiv.ua/komitet/ru/documents (22 October 2014).

Demetr, Nadezhda, Nikolai Bessonov and Niklolai Kutenkov. Istoriya tsygan - novyi vzgliad. Voronezh: IPF, 2000.

Do 70-rokovin tragedii Babynogo Yaru. Dokumental'na vystava. Kyiv: Derzhavna Arkhivna Sluzhba Ukrainy, 2011.

Evstafieva, Tatiana. "Babi Yar vo vtoroi polovine XX veka." Babi Yar: chelovek, vlast', istoriya. Dokumenty i materialy. Ed. Tatiana Estafieva and Vitalii Nakhmanovich. Kyiv: Vneshtorgizdat, 2004. 187-206.

Evstafieva, Tatiana. “K istorii ustanovleniya pamiatnika v Bab’em Yaru.” Evreiskii obozrevatel." 11 (30 June 2002).

Forest, Benjamin and Juliet Johnson. "Unravelling the Threads of History: Soviet-Era Monuments and Post-Soviet National Identity." Annals of the Association of American Geographers 92.3 (2002): 524-547.

Frydman, Aleksandr. "Neviadomy genocide: znishchenne belaruskikh tsyhanou u 1941-1944." ARCHE. 2 (2004): 2-13.

Gabrielson, Tatiana. Propaganda of Romani Culture in Post-Soviet Ukraine. PhD dissertation. The University of Texas at Austin. 2006, 127-132.

Gitelman, Zvi. "Politics and the historiography of the Holocaust in the Soviet Union." Bitter legacy: confronting the Holocaust in the USSR. Ed. Zvi Gitelman. Bloomington: Indiana University Press, 1997. 14- 43. 
Golbert, Rebecca. "Holocaust Sites in Ukraine: Pechora and the Politics of Memorialization." Holocaust and Genocide Studies 18.2 (2004): 205-233.

Grossman,Vasily. “Doroga na Berlin.” Krasnaya Zvezda 38.6026 (15 February 1945): 3.

Hedlund, Stefan. Russian Path Dependence. London: Routledge, 2005.

Holocaust i suchasnist'. Special issue on the history of Roma Holocaust. 2.16 (2009).

Hrynevich, Olena. "Romi Ukrainy i Mikolaevshchyna." Naukovi zapiski. Zbirnik prats molodikh vchenikh ta aspirantiv. Kyiv: National Academy of Sciences, 2008. 136-145.

Hrytsak, Yaroslav. Strasti za natsionalizmom. Kyiv: Krytyka, 2004.

Istorichnyi ta etnokulturnyi rozvitok tsygan (roma) Ukrainy. Donetsk, 2006.

Jilg, Wilfried. "The Politics of History and the Second World War in Post-Communist Ukraine." Jahrbücher für Geschichte Osteuropas 54.1 (2006): 50-81.

Kalinin, Valdemar. Zagadka baltiiskikh tsygan. Minsk: Logvinov, 2005.

Kapralski, Slawomir. "Symbols and Rituals in the Mobilisation of the Romani National Ideal." Studies in Ethnicity and Nationalism 12.1 (2012): 64-81.

Kendzior, Petro, Ed. Razom na odnii zemli. Istoriya Ukrainy bogatokul'turna. Lviv: ZUKTs, 2012.

Ilya Zaslavskii Ed. Kniga Pamiati. Imena pogibshikh v Bab’em Yaru.. Kyiv: Oberih, 1991.

Konstatinovskii, Ilya. "Zemlia Moldavii." Izvestia 137.8439 (10 June 1944): 3.

Korsun, Ivan. “Tsyganskaya doroga. Vospominaniya.” Holocaust $i$ suchasnist'. 2.6 (2009): $172-210$.

Kotljarchuk, Andrej. "World War II Memory Politics: Jewish, Polish and Roma Minorities of Belarus."The Journal of Belarusian Studies 1.7 (2013): 7-40.

Kotljarchuk, Andrej. "Palityka pamiaci u suchasnai Belarusi. Memaryialy druhoi susvetnai vainy i etnichnyia menshastsi krainy.” ARCHE 2 (2013): 173-194.

Kotljarchuk, Andrej. "Natsistskii genotsid tsygan na territorii okkupirovannoi Ukrainy: rol' sovteskogo proshlogo v sovremennoi politike pamiati." Holocaust $i$ suchasnist 1.12 (2014): $24-50$.

Kotljarchuk, Andrej. "Nazi Genocide of Roma in Belarus and Ukraine: the significance of census data and census takers." Etudes Tsigane 1 (2015).

Kruglov, Aleksandr. "Genocide tsygan v Ukraine 1941-1944: statistiko-regional'nyi aspect." Holocaust i suchasnist' 2.16 (2009): 83-133.

Kruglov, Aleksandr. Sbornik dokumentov i materialov ob unichtozhnenie natsistami evreev Ukrainy v 1941-44. Kyiv: Institut Judaiki, 2002.

Kuznetsov, Anatoly. Babi Yar. A documentary novel. New York: The Dial Press, 1967.

Kuznetsov, Anatoly. Babi Yar. Roman-dokument. Moskva: Molodaya gvardiya, 1967.

Kuznetsov, Anatoly. Babi Yar. Roman-dokument. Frankfurt am Main: Posev, 1970.

Lemon, Alaina. Between two fires Gypsy performance and Romany memory. From Pushkin to Postsocialism. Durham: Duke University Press, 2000.

Levitas, Ilya. “Nerazgadannye tainy Bab’ego Yara.” Evreiskie vesti/, 17.18 (1993).

Lustiger, Arno. Stalin i evrei: Tragicheskaia istoriya Evreiskogo antifashistskogo komiteta $i$ sovetskikh evreev. Moscow: Rosspen, 2008.

Mankoff, Jeff. "Babi Yar and the struggle for memory, 1944-2004." Ab Imperio 2 (2004): $393-415$.

Margalit, Gilad. Germany and its gypsies: a post-Auschwitz ordeal. Madison: University of Wisconsin Press, 2002. 
Marushiakova, Elena and Vesselin Popov. "Holocaust and the Gypsies. The Reconstruction of the Historical Memory and Creation of New National Mythology." Beyond Camps and Forced Labour. Current International Research on Survivors of Nazi Persecution. Eds. Johannes-Dieter Steinert and Inge Weber-Newth. Osnabrück: Secolo, 2006. 805-826.

Materialy mizhnarodnoi tsyhanoznavchoi konferentsii Romy Ukrainy iz minulogo $v$ maibutne. Kyiv: Justinian, 2008.

Mitsel, Mikhail. "Zapret na uvekovechivanie pamiati kak sposob zamalchivania Holocausta." Holocaust i suchasnist' 1.2 (2007): 9-30.

Muzychenko, Yaroslava. "Tsigans'ke gore.” Ukraina moloda (9 August 2008).

Nakhmanovich, Rafail. "Babi Yar-1966: kak eto bylo.” Maidan (28 September 2006).

Nakhmanovich, Vitalii. "Rasstrely i zakhoroneiya v raione Bab'ego Yara vo vremia nemetskoi okkupatsii goroda Kyiva 1941-43." Babi Yar: chelovek, vlast', istoriya. Dokumenty i materialy. Ed. Tatiana Estafieva and Vitalii Nakhmanovich. Kyiv, 2004. 84-163.

Nora, Pierre and Lawrence Kritzman. Realms of memory: rethinking the French past. 1. New York: Columbia University Press, 1996; Realms of memory: rethinking the French past. 2. New York: Columbia University Press, 1997.

Nordström, Anders. The interactive dynamics of regulation: exploring the Council of Europe's monitoring of Ukraine. Stockholm: Stockholm University Press, 2008.

"Nota narodnogo komissara inostrannykh del SSSR tov. V. M. Molotova ot 6 ianvaria 1942 goda." Nurnbergskii process. Sbornik materialov. Moscow: Gosudarstvennoe izdatel'stvo iuridicheskoi literatury, 1954. 504-517.

Official website of Larysa Skoryk. http://www.skoryk.net.ua/sakralna-arhitektura-monumenty/ babyn-yar (22 October 2014).

Ofitsinsky, Roman. “Romi i prymusova prats ana Zakarpatti 1939-1944.” Romologia: istoria ta suchasnist'. Ed. Roman Ofitsinsky. Uzhhorod: Lira, 2013, 76-82.

Oldberg, Ingmar. "Both victims and perpetrators. Ukraine's problematic relationship to the Holocaust." Baltic worlds 4.2 (2011): $40-43$.

Osipian, Alexander. "Ethnic Cleansings and Memory Purges: The Ukrainian-Polish Borderland in 1939-1947 in Modern Politics and Historiography." Ab Imperio 2 (2004): 297-328.

“Pamiatnik pogibshim v Bab’em Yaru." Pravda (3 April 1945): 3.

Peresleduvannia ta vbivstva romiv na terenakh Ukrainy u chasi druhoi svitovoi viini. Zbirnik dokumentiv ta spohadiv. Ed. Mikhail Tyaglyy. Kyiv: Ukrainian Centre for Genocide Studies, 2013.

Jerzy Dębski and Joanna Talewicz-Kwiatkowska. Ed. Prześladowania i masowa zagłada Romów podczas II wojny światowej w świetle relacji i wspomnień.. Warszawa: Romski Instytut Historyczny, 2008.

Pickford, Henry. "Conflict and Commemoration: Two Berlin Memorials." Modernism modernity 12.1 (2005): $133-173$.

Pirohova Levada. Narysy. Kyiv: Prosvita, 2012.

Platonov, Vladimir. “Babiy Yar: Tragedia o tragedii.” Zerkalo Nedeli 39 (1997).

Portnov, Andrii. “Uprazhneniya s istoriei po-ukrainski.” Ab Imperio 3 (2007): 93-138.

“Rech' tovarishcha N. S. Khrushcheva." Pravda 89 (10 March 1963): 1, 4.

"Resolution 2085-IV of the Verkhovna Rada of Ukraine on the International Day of the Roma Holocaust."Vidomosti Verkhovnoi Rady Ukrainy. 2 (2005): 65.

“Romi vimahaut'vid Azarova vshanuvaty i ikhni Holocaust." Ukrains'ka Pravda, 13 July 2011. 
Schäuble, Michaela. "How History Takes Place: Sacralized Landscapes in the Croatian-Bosnian Border Region.” History and Memory 23.1 (2011): 23-61.

Schleifman, Nurit. "Moscow's Victory Park: A Monumental Change." History and Memory 13. 2 (2001): 5-34.

Stan dotrimannia Ukrainoiu evropeiskikh standartiv z prav $i$ svobod ludyny. Kyiv: Verkhovna Rada Press, 2010.

Stauber, Roni and Raphael Vago. "The Politics of Memory: Jews and Roma Commemorate their Persecution."The Roma: A Minority in Europe. Historical, Political and Social Perspectives. Eds. Roni Stauber and Raphael Vago. Budapest: Central European University Press, 2007. 117-132.

Stewart, Michael. "Remembering without Commemoration: the Mnemonics and Politics of Holocaust memories among European Roma." Journal of the Royal Anthropological Institute 10.3 (2004): 561-582.

"Soobshchenie Chrezvychainoi Gosudarstvennoi Komissii po ustanovleniu i rassledovaniu zlodeianii nemetsko-fashistskikh zakhvatchikov i ikh soobshchnikov o razrusheniyakh I zverstvakh sovershennykh nemetsko-fashistskim zakhvatchikami v gorode Kyive." Izvestia 50.8352 (29 February 1944): 3.

"Soobshchenie Chrezvychainoi Gosudarstvennoi Komissii po ustanovleniu i rassledovaniu zlodeianii nemetsko-fashistskikh zakhvatchikov i ikh soobshchnikov." Izvestia 205. 8507 (29 August 1944): 3.

Sumyinfo. Official News Portal of Sumy region. http://sumyinfo.com (22 October 2014).

"Svidetel'stvo zhitelei goroda Kyiva khudizhnika Nikolaya Adrianovicha Priakhova i professora Ivana Nikolaevicha Zhitova i drugikh o massovykh rasstrelakh v Bab'em yaru." Central State Archive of the supreme power and administration of Ukraine (TsDAVO). Fond R- 4620, opis 3, sprava 243a, list 38.

The Black Book: the Nazi crime against the Jewish people. Published by the Jewish Black Book Committee, New York: Duell, Sloan and Pearce, 1946.

Troitskii, P. “Po stranitsam zhurnalov.” Izvestia 19.15413 (20 January 1967): 5.

Tyaglyy, Mikhail. "Nazi occupational policies and the mass murder of the Roma in Ukraine." The Nazi genocide of the Roma. Reassessment and Commemoration. Ed. Anton Weiss-Wendt. New York-Oxford: Berghahn Books, 2013. 120-152.

Tyaglyy, Mikhailo. "Babyn Yar yak mistse masovogo vynishchennia ukrainskikh romiv: typova model?" Paper presented on the international conference Babi Yar: mass killings and its memory. Kyiv, 25 October 2011.

Ventsel, Tatiana. “Tsygane.” Bolshaya Sovetskaya Enciklopedia/. 28. Moscow, 1978. $606-607$.

Yarmoluk, Serhii. “Kvitok do Romanistana.” Den', 30 May 1998.

Zajava Ministerstva kultiry Ukrainy z nagodi Mizhnarodnogo dnia Holocaustu romiv. 2 August 2013. http://mincult.kmu.gov.ua (22 October 2014).

Zimmermann, Michael. Rassenutopie und Genozid: die nationalsozialistische 'Lösung der Zigeunerfrage'. Hamburg: Christians, 1996.

Zinchenko, Natalia. "Baron i kosmos." Aratta, 17 February 2009. 